\title{
Efficacy of on-farm use of ultraviolet light for inactivation of bacteria in milk for calves ${ }^{1}$
}

\author{
S. L. Gelsinger, ${ }^{*}$ A. J. Heinrichs, ${ }^{* 2}$ C. M. Jones, ${ }^{*}$ R. J. Van Saun, $†$ D. R. Wolfgang, $†$ C. M. Burns, $\dagger$ \\ and H. R. Lysczek† \\ *Department of Animal Science, and \\ †Department of Veterinary and Biomedical Science, Pennsylvania State University, University Park 16802
}

\begin{abstract}
Ultraviolet light is being employed for bacterial inactivation in milk for calves; however, limited evidence is available to support the claim that UV light effectively inactivates bacteria found in milk. Thus, the objective of this observational study was to investigate the efficacy of on-farm UV light treatment in reducing bacteria populations in waste milk used for feeding calves. Samples of nonsaleable milk were collected from 9 Pennsylvania herds, twice daily for $15 \mathrm{~d}$, both before and after UV light treatment $(\mathrm{n}=60$ samples per farm), and analyzed for standard plate count, coliforms, noncoliform, gram-negative bacteria, environmental and contagious streptococci, coagulase-negative staphylococci, Streptococcus agalactiae, Staphylococcus aureus count, and total solids percentage, and log reduction and percentage log reduction were calculated. Data were analyzed using the mixed procedure in SAS. In all bacteria types, samples collected after UV treatment contained significantly fewer bacteria compared with samples collected before UV treatment. Weighted least squares means for log reduction (percentage log reduction) were $1.34(29 \%), 1.27(58 \%), 1.48(53 \%), 1.85$ (55\%), 1.37 (72\%), 1.92 (63\%), $1.07(33 \%)$, and 1.67 $(82 \%)$ for standard plate count, coliforms, noncoliform, gram-negative bacteria, environmental and contagious streptococci, Strep. agalactiae, coagulase-negative staphylococci, and Staph. aureus, respectively. A percentage log reduction greater than $50 \%$ was achieved in 6 of 8 bacteria types, and 43 and $94 \%$ of samples collected after UV treatment met recommended bacterial standards for milk for feeding calves. Based on these results, UV light treatment may be effective for some, but not all bacteria types found in nonsaleable waste
\end{abstract}

Received July 15, 2013.

Accepted January 31, 2014.

${ }^{1}$ This research is a component of NC-1042; Management Systems to Improve the Economic and Environmental Sustainability of Dairy Enterprises.

${ }^{2}$ Corresponding author: ajh@psu.edu milk. Thus, farmers should take into account the bacteria types that may need to be reduced when considering the purchase of a UV-treatment system.

Key words: ultraviolet light, waste milk, calf

\section{INTRODUCTION}

Pasteurized waste milk is considered a nutritious and low-cost liquid feed for dairy calves. Surveys show that it is gaining popularity in the United States (USDA, 2010), and studies show its value as a feed source for the neonate (Jamaluddin et al., 1996). It is most often recommended to pasteurize waste milk before feeding calves to reduce potential pathogen populations (McGuirk, 2008). Jamaluddin et al. (1996) reported that calves fed pasteurized milk were $3.7 \mathrm{~kg}$ heavier at 180 d of age compared with calves fed unpasteurized milk. This difference was attributed to fewer incidents and less severe cases of scours in the preweaning period in calves fed pasteurized milk. In addition, Godden et al. (2005) demonstrated a $\$ 0.69 /$ calf per day reduction in costs when calves were fed pasteurized nonsaleable milk rather than milk replacer. High-temperature, shorttime pasteurization (HTST; $72^{\circ} \mathrm{C}, 15 \mathrm{~s}$ ) and batch pasteurization $\left(63^{\circ} \mathrm{C}, 30 \mathrm{~min}\right)$ are 2 types of heat treatment that have been adopted on farms to reduce the bacterial populations in milk fed to calves (ElizondoSalazar et al., 2010). However, heat pasteurization is a high-energy input process that can increase the cost associated with feeding milk to calves (Krishnamurthy et al., 2007; 2008).

Ultraviolet light treatment is an alternative method for bacterial inactivation that has been approved for use in fruit juice (FDA, 2000), and has been suggested as a possible alternative in milk processing as well (Matak et al., 2005). Ultraviolet light inactivates bacteria by creating covalent bonds between nucleic acids within bacterial DNA (Koutchma et al., 2009), thus rendering the bacteria unable to reproduce. Factors that influence the effectiveness with which UV light inactivates bacteria are the types and number of organisms present, dose of UV light, as well as solids concen- 
tration, volume, and transparency of the liquid medium (Guerrero and Barbosa-Canovas, 2004). Research trials conducted with juice have shown that, when properly applied, UV treatment is able to consistently attain the FDA-required 5-log decrease in microorganisms (FDA, 2011).

Results from experiments using UV light to inactivate bacteria in milk are more variable. Krishnamurthy et al. $(2007,2008)$ reported decreases in Staphylococcus aureus counts ranging from 1.05 to $6.61 \log _{10} \mathrm{cfu} / \mathrm{mL}$ in milk foam, 0.14 to $8.55 \log _{10} \mathrm{cfu} / \mathrm{mL}$ in stationary milk, and 0.55 to $7.26 \log _{10} \mathrm{cfu} / \mathrm{mL}$ in flowing milk. Populations of Listeria monocytogenes were decreased by $5.62 \log _{10} \mathrm{cfu} / \mathrm{mL}$ in goat's milk exposed to a cumulative dose of $28.4 \mathrm{~mJ} / \mathrm{mL}$ of UV light (Matak et al., 2005). A more recent study found reductions $>2 \log$ in Escherichia coli, Staphylococcus spp., total coliforms, and mesophilic aerobic microorganisms after exposure to $13,870 \mathrm{~mJ} / \mathrm{mL}$ (Engin and Yuceer, 2012). Miller et al. (2012), using a UV dose of $114,231 \mathrm{~mJ} / \mathrm{mL}$, were able to attain $\log$ reductions of $3.36,2.89$, and 2.94 in skim, $2 \%$, and whole milk inoculated with E. coli. However, UV light treatment seems to be less effective for inactivation of Mycobacterium avium ssp. paratuberculosis, the causative agent of Johne's Disease in cattle (Stabel, 2001). Altic et al. (2007) reported a maximum $2.6 \log$ reduction in whole milk exposed to $2,860 \mathrm{~mJ} /$ $\mathrm{mL}$ of UV light. In addition, Donaghy et al. (2009) reported a $1.1 \log$ decrease using a UV dose of 1,836 mJ/ $\mathrm{mL}$. However, these reductions are considerably smaller than those reported from batch or HTST pasteurizers (Stabel, 2001; Stabel et al., 2004, respectively), where no $M$. avium ssp. paratuberculosis were isolated after heating. In both cases, milk was inoculated to levels in excess of $5 \log _{10} \mathrm{cfu} / \mathrm{mL}$.

A flow-through, pulsed UV treatment system commercially available for bacterial inactivation in waste milk for calves uses a series of UV lights, and milk flows through the system multiple times to increase the cumulative dose of UV light. Flow-through systems have been studied under a laboratory setting (Krishnamurthy et al., 2008). However, no data have been published concerning the efficacy of this technology applied on farms. Thus, the objective of our study was to describe the observed efficacy of UV light treatment systems in use on a sample of dairy farms in Pennsylvania. The total solids suspended within a liquid have previously been shown to affect the efficacy of UV light for bacterial inactivation (Miller et al., 2012). A secondary objective of our experiment was to assess the effect of total solids percentage on bacterial inactivation and describe the variation in total solids percentage between individual batches of milk.

\section{MATERIALS AND METHODS}

\section{Description of Farms and UV Treatment System}

Nine farms were chosen based on known use of UV light treatment of milk for feeding to calves and convenience of sample collection. Selected herds were located in the southeast, south-central, and northcentral regions of Pennsylvania and represented various management strategies, including one farm utilizing robotic milking machines. All farms used the same UV treatment system (UV Pure, GEA Farm Technologies Inc., Naperville, IL), with the systems being in use on the farms from 2 to 48 mo at time of sampling. The UV Pure system is a completely automated system. Milk is pumped from a retention tank, through the UV reactor, and returned to the retention tank. Milk cycles through the system at least 16 times. The system will automatically increase the number of cycles to maintain a similar total dose of UV radiation as the UV light bulbs age. The UV reactor consists of 2 or 3 UV lights, depending on the size of the system. Larger systems include more lights to maintain efficiency while treating large volumes of milk. The lights are housed inside a quartz tube and milk is exposed to UV light by flowing over the outside of the quartz tube. After UV treatment, milk is heated to approximately $38^{\circ} \mathrm{C}$ for feeding. Each UV system was washed with an initial water rinse followed by detergent and acid wash cycles that were programmed to occur automatically after each use. Each system included a monitoring system for the UV lights to alert the operator when lights should be replaced. No UV lights had been replaced in any system at the beginning of sampling. Milk handling before entering the retention tank of the UV treatment system ranged from no human contact to employees moving milk into the retention tank via plastic buckets.

\section{Sample Collection}

Samples of nonsaleable whole milk were collected by farm personnel into sterile, plastic, $15-\mathrm{mL}$ conical tubes (VWR International LLC, Radnor, PA) before and after UV treatment every morning and night for 15 d. Farm personnel were instructed to allow milk to agitate within the retention tank, then, using a gloved hand, collect samples, and freeze immediately after collection. Supplies and training for sample collection were provided by the authors before the sampling period. Samples were transported on ice from individual farms to the Pennsylvania State University on a weekly or biweekly basis throughout the sampling period, and stored at $-20^{\circ} \mathrm{C}$ before bacterial analysis. At the time of transport, samples were examined 
to ensure that all milk appeared frozen. Apart from initial training and this observation, no other methods were used to control for possible differences in sample collection and handling by farm personnel. All samples were collected in the months of July, August, and September of 2012.

\section{Microbial Analysis}

Each milk sample $(\mathrm{n}=544)$ was analyzed for SPC, coliforms (CC), noncoliform gram-negative bacteria (NC), environmental and contagious streptococci (ES and CS, respectively), CNS, Streptococcus agalactiae (SAG), and Staphylococcus aureus (SA) count (Jayarao et al., 2004). MacConkey's, Edward's Modified, and Baird-Parker agars were used to culture gram-negative bacteria, Streptococcus spp., and Staphylococcus spp., respectively (Jayarao et al., 2004). As per standard laboratory procedure, duplicate plates of each type were created for each milk sample. Bacterial colonies were counted following a 48-h incubation period at $32(\mathrm{SPC})$ or $37^{\circ} \mathrm{C}$ (all others). Samples that yielded plates too numerous to count at $48 \mathrm{~h}$ underwent subsequent freeze-thaw cycles, were diluted in PBS, and recultured to obtain the most accurate count. Suspect SAG and SA colonies were subcultured on blood agar and confirmed using API 20 Strep or API Staph, respectively (BioMerieux, Hazelwood, MO; Jayarao et al., 2004).

Results from duplicate plates were averaged and transformed to $\log _{10} \mathrm{cfu} / \mathrm{mL}$ for statistical analysis $\left[\log _{10}(\mathrm{x}+1)\right]$. Efficacy of UV treatment was evaluated using the calculated log reduction and percentage log reduction. Log reduction was calculated for each beforeafter sample pair by $\left(\log _{10} \mathrm{cfu} / \mathrm{mL}\right.$ before UV treatment - $\log _{10} \mathrm{cfu} / \mathrm{mL}$ after UV treatment) and percentage log reduction by $\left[\left(\log\right.\right.$ reduction $\div \log _{10} \mathrm{cfu} / \mathrm{mL}$ before UV treatment) $\times 100]$. Samples with zero log reduction due to no bacterial isolates before UV light treatment were not included in the analysis to avoid bias in the output. However, negative log reductions, observed when the posttreatment samples contained greater numbers of bacteria than pretreatment samples, were included in the analysis. Percentage log reduction could not be calculated for samples in which no bacteria were isolated from the sample taken before UV light treatment.

\section{Total Solids Percentage}

Total solids percentage was estimated at the time of bacterial culture using a Brix refractometer (Atago Co. Ltd., Tokyo, Japan) and the regression equation reported by Moore et al., (2009).

\section{Statistical Analysis}

All data were analyzed using the mixed procedure in SAS (Version 9.3, SAS Institute Inc., Cary, NC). Statistical significance was declared when $P<0.05$ and tendencies when $P<0.10$. Bacterial counts from duplicate plates were averaged to create a single estimate of the bacterial population within each milk sample. Normality of bacterial count data was evaluated visually using normality plots in the univariate procedure in SAS. Data was transformed to $\log _{10} \mathrm{cfu} / \mathrm{mL}$ for analysis to satisfy the assumption of normal distribution. Transformed bacterial counts $\left(\log _{10} \mathrm{cfu} / \mathrm{mL}\right)$ from individual milk samples were analyzed using the model

$$
Y_{i j k l}=\mu+\alpha_{i}+\beta\left(\gamma_{k}\right)_{j}+c_{l}+\epsilon_{i j k l},
$$

where $Y_{i j k l}$ represents the bacterial count $\left(\log _{10} \mathrm{cfu} /\right.$ $\mathrm{mL}) ; \mu$ represents the mean bacterial count $\left(\log _{10} \mathrm{cfu} /\right.$ $\mathrm{mL}) ; \alpha_{i}$ represents the fixed effect of period $(i=1$, 2 ; before or after UV treatment); $\beta\left(\gamma_{k}\right)_{j}$ represents the fixed effect of time ( $k=1,2$; morning or evening) within day $(j=1 \ldots 15) ; c_{l}$ represents the random effect of farm $(l=1 \ldots 9)$; and $\epsilon_{i j k l}$ represents the residual error. All farms included in our study treated milk with UV light 2 times per day. For this reason, only 2 time measurements were collected per day (morning and evening). Thus, time within day was included as a nested fixed effect instead of using repeated measures analysis. Period was included in the model to compare mean bacterial count before with mean count after UV treatment. Farm was included as a random effect to account for clustering of data by farm. Appropriateness of the model was assessed using the residual plots in SAS to investigate the distribution and independence of error terms.

Log reduction and percentage log reduction were calculated for individual batches of milk on each farm and analyzed using the model

$$
Y_{i j k l}=\mu+\delta X_{i j k}+\beta\left(\gamma_{k}\right)_{j}+c_{l}+\epsilon_{i j k l}
$$

In this model, $Y_{i j k l}$ represents the log reduction or percentage log reduction; $\mu$ represents the overall mean log reduction or percentage log reduction; $\delta X_{i j k}$ represents the covariate of total solids percentage; $\beta\left(\gamma_{k}\right)_{j}$ represents the fixed effect of time ( $k=1,2$; morning or evening) within day $(j=1 \ldots 15) ; c_{l}$ represents the random effect of farm $(l=1 \ldots 9)$; and $\epsilon_{i j k l}$ represents the residual error. Prior to inclusion of total solids percentage in the model, the effect of UV treatment and individual batch of milk on total solids percentage measurement was assessed using the mixed procedure of SAS with period 
Table 1. Bacteria counts ${ }^{1}$ and total solids percentage in nonsaleable milk before $(\mathrm{n}=272)$ and after $(\mathrm{n}=272)$ UV treatment on 9 Pennsylvania dairy farms

\begin{tabular}{|c|c|c|c|c|c|}
\hline $\begin{array}{l}\text { Item } \\
\text { (cfu/mL, unless otherwise noted) }\end{array}$ & Mean & $\mathrm{SD}$ & Median & Maximum & Minimum \\
\hline \multicolumn{6}{|l|}{ Standard plate count } \\
\hline Before UV treatment & $3,057,005$ & $20,667,236$ & 27,760 & $296,000,000$ & 200 \\
\hline After UV treatment & 511,912 & $4,328,145$ & 2,000 & $57,000,000$ & 0 \\
\hline \multicolumn{6}{|l|}{ Coliform } \\
\hline Before UV treatment & 40,434 & 159,329 & 135 & $1,690,000$ & 0 \\
\hline After UV treatment & 11.503 & 106,983 & 10 & $1,460,000$ & 0 \\
\hline \multicolumn{6}{|l|}{ Noncoliform gram-negative } \\
\hline Before UV treatment & 164,507 & 838,771 & 1,445 & $9,760,000$ & 0 \\
\hline After UV treatment & 8,335 & 58,385 & 30 & 720,710 & 0 \\
\hline \multicolumn{6}{|l|}{ Environmental streptococci } \\
\hline Before UV treatment & 167,497 & 760,084 & 3.550 & $8,400,000$ & 0 \\
\hline After UV treatment & 40,555 & 398,538 & 40 & $5,200,000$ & 0 \\
\hline \multicolumn{6}{|l|}{ Contagious streptococci } \\
\hline Before UV treatment & 76,554 & $1,015,217$ & 20 & $16,700,000$ & 0 \\
\hline After UV treatment & 2,636 & 39,291 & 0 & 648,000 & 0 \\
\hline \multicolumn{6}{|l|}{ Streptococcus agalactiae } \\
\hline Before UV treatment & 2,475 & 19,742 & 0 & 276,000 & 0 \\
\hline After UV treatment & 147 & 1,889 & 0 & 31,000 & 0 \\
\hline \multicolumn{6}{|l|}{ Coagulase-negative staphylococci } \\
\hline Before UV treatment & 51,069 & 661,005 & 2,175 & $10,900,000$ & 0 \\
\hline After UV treatment & 13,433 & 99,192 & 150 & $1,032,000$ & 0 \\
\hline \multicolumn{6}{|l|}{ Staphylococcus aureus } \\
\hline Before UV treatment & 222 & 1,997 & 0 & 31,840 & 0 \\
\hline After UV treatment & 80 & 1,194 & 0 & 19,680 & 0 \\
\hline Total solids ${ }^{2}(\%)$ & 10.38 & 0.56 & 10.36 & 13.86 & 8.27 \\
\hline
\end{tabular}

${ }^{1}$ All bacterial cultures were completed in duplicate. Values represent the average of duplicate plates.

${ }^{2}$ Total solids before and after UV treatment were averaged.

and time within day as fixed effects and farm included as a random effect. Time within day was included in the model for log reduction and percentage log reduction to account for different batches of milk and was used to allow calculation of least squares means estimates. Normality of log reduction and percentage log reduction data values was assessed using normality plots in the univariate procedure in SAS before fitting the model. Residual distribution and independence were evaluated using residual plots.

Log reduction and percentage log reduction data for SAG were analyzed separately, excluding the random effect of farm because this bacteria type was only isolated on 1 farm. Day was included as a fixed effect and total solids as a covariate; however, time was not nested within day to avoid overspecification of the model. When total solids significantly affected log or percentage log reduction, Proc Corr was used to determine the strength of the correlation between total solids and reduction of the specific bacteria affected.

\section{RESULTS AND DISCUSSION}

A total of 544 (272 before treatment; 272 after treatment) samples were collected from 9 farms. Sixty samples were supplied from each farm, and, due to a miscommunication, one farm collected 2 extra samples, which were included in the analysis and not expected to bias results. A description of the bacterial counts in samples collected before and after UV treatment is presented in Table 1.

At least 1 type of bacteria was isolated from each of the 272 samples collected before and in $99 \%$ of the samples collected after UV light treatment. Mean SPC before treatment was 3,057,005 $\mathrm{cfu} / \mathrm{mL}$, with maximum and minimum values of $296,000,000$ and $200 \mathrm{cfu} / \mathrm{mL}$, respectively. Due to the skewed nature of bacterial count data, the median, $27,760 \mathrm{cfu} / \mathrm{mL}$, was much lower than the mean, and $64 \%$ of samples contained fewer than 100,000 cfu/mL (Tables 1 and 3 ). Other studies reported a lower median and smaller ranges in bacteria counts in raw milk (Jorgensen et al., 2006; Elizondo-Salazar et al., 2010); however, the present data are similar to SPC counts presented from colostrum samples (Fecteau et al., 2002; Houser et al., 2008). Mean and maximum counts of SA, and mean counts for CC, ES, and SAG were similar to values previously reported in raw milk (Jorgensen et al., 2006). Elizondo-Salazar et al. (2010) found a median count for CC bacteria similar to the value in the present study; however, median bacterial populations of all other bacteria types were greater than those reported by Elizondo-Salazar et al. (2010). Staphylococcus aureus or SAG were not isolated by Elizondo-Salazar et al. 
(2010). Median bacterial counts for CNS and SA were similar, CC was lower, NC and total Streptococci counts were higher, and a wider range was observed for CS, CNS, and SA compared with median counts and ranges reported in colostrum (Houser et al., 2008). Differences in raw milk-handling procedures before UV treatment may be a cause of high-bacteria counts; however, the focus of the current study was to evaluate the change in bacterial populations between samples collected before and after UV treatment. Thus, no discrimination was made based on milk-handling procedures when selecting farms for our study.

A description of the total solids percentage found in milk samples is also presented in Table 1. Milk total solids averaged $10.4 \pm 0.56 \%$, with minimum and maximum values of 8.3 and $13.9 \%$, respectively. The relationship between Brix percentage and total solids percentage reported by Moore et al. (2009) was based on fresh milk samples. However, samples in our study were frozen and thawed before measurement with a Brix refractometer. Despite this difference in methodology, total solids values in Table 1 are plausible, given the 5.1 to $13.5 \%$ range reported in waste milk by Moore et al. (2009).

Results from statistical analysis of total solids showed a significant effect of period $(P=0.03)$ and time within day $(P=0.01)$, indicating that total solids percentage increased following treatment with UV light and was different among batches of milk. Least squares means estimates were 10.30 and $10.41 \%$ for samples collected before and after UV treatment, respectively. However, to the extent of the authors' knowledge, UV light treatment is not known to affect total solids percentage; thus, despite statistical significance, these values were not considered practically significant, and total solids percentage from samples collected before and after UV treatment was averaged to create a single total solids percentage for each batch of milk. These average values $(10.38 \pm 0.16)$ were included as a covariate to model log reduction and percentage log reduction. An increase in total solids percentage was significantly associated with a decreased log reduction in ES and CNS and a decreased percentage log reduction of CNS. In addition, $\log$ reduction of SPC and percentage log reduction of ES also tended to decrease with greater total solids percentage. The correlation coefficients for total solids and $\log$ reduction of ES, CNS, and SPC were -0.24 , -0.11 , and -0.15 , respectively. Coefficients for percentage $\log$ reduction of CNS and ES and total solids were -0.09 and -0.13 , respectively. No significant effect of total solids percentage was observed for other bacteria types. The effect of total solids percentage on the efficacy of UV light treatment has previously been shown by Miller et al. (2012), who reported a log reduction
$>2$ in milk powder reconstituted to $9.8 \%$ solids, but a $\log$ reduction $<1$ at 25 and $45 \%$ solids. Lower variation in total solids percentage may explain the lack of significance of total solids percentage for certain bacteria types analyzed in the current study.

A comparison of the reverse-transformed least squares means bacteria count for each bacteria type before and after UV treatment is shown in Table 2. Samples collected after UV treatment contained significantly fewer bacteria compared with samples collected before UV treatment $(P<0.01)$. Data in Table 2 represent a comparison of the mean bacteria count between all samples collected before and all samples collected after UV treatment. However, these data do not give a comparison of the efficacy of UV light within individual milk samples; they merely indicate a significant difference in the average counts.

The distribution of samples by bacteria count (cfu/ $\mathrm{mL}$ ) is shown in Table 3. For all bacteria types, with the exception of SPC, at least 1 sample was found in which no bacterial colonies were isolated before UV light treatment. Environmental bacteria (CC, NC, ES, CNS) were most frequently isolated from milk samples before UV light treatment compared with other bacteria types. Coliform bacteria, NC, and ES were isolated in 83,88 , and $96 \%$ of samples, respectively. Colonies of CNS were isolated in almost all (99.6\%) samples collected before UV light treatment. Following UV light treatment, CC, NC, ES, and CNS were cultured in 53, 64,71 , and $90 \%$ of milk samples, respectively.

Contagious mastitis pathogens (CS, SAG, SA) were isolated in $68 \%, 10 \%$, and $21 \%$ of samples before UV treatment, respectively; and $33 \%, 6 \%$ and $6 \%$ samples post UV treatment, respectively. All samples containing SAG were collected on a single farm, and SA was isolated on 3 farms.

The Grade A Pasteurized Milk Ordinance requires SPC $<100,000 \mathrm{cfu} / \mathrm{mL}$ and $\mathrm{CC}<100 \mathrm{cfu} / \mathrm{mL}$ in milk before pasteurization for human consumption (FDA, 2013). Of the 272 samples collected before UV light treatment, 64 and $44 \%$ contained SPC $<100,000 \mathrm{cfu} /$ $\mathrm{mL}$ and $\mathrm{CC}<100 \mathrm{cfu} / \mathrm{mL}$, respectively (Table 3). Forty-three percent of samples collected before UV treatment met both of these FDA standards. Postpasteurization requirements are $\mathrm{SPC}<20,000 \mathrm{cfu} / \mathrm{mL}$ and $\mathrm{CC}<10 \mathrm{cfu} / \mathrm{mL}$ (FDA, 2013). One hundred twentyeight samples (47\%) met both of these criteria post-UV treatment. Eighty-four percent of samples contained $<20,000 \mathrm{cfu} / \mathrm{mL}$ of SPC and $47 \%$ contained $<10 \mathrm{cfu} /$ $\mathrm{mL}$ of CC (Table 3). Suggestions of maximum bacterial contamination in milk for calves are SPC $<10,000 \mathrm{cfu} /$ $\mathrm{mL}$, fecal coliforms and $\mathrm{SA}<10 \mathrm{cfu} / \mathrm{mL}$, and $\mathrm{NC}, \mathrm{ES}$, $\mathrm{CS}$, and CNS $<5,000 \mathrm{cfu} / \mathrm{mL}$ (McGuirk, 2008). Coliform bacteria were not divided into fecal and nonfecal 
Table 2. Least squares means bacteria counts ${ }^{1}$ (reverse-transformed from $\log _{10} \mathrm{cfu} / \mathrm{mL}$ ) in nonsaleable milk before $(\mathrm{n}=272)$ and after $(\mathrm{n}=272)$ UV treatment on 9 Pennsylvania dairy farms

\begin{tabular}{|c|c|c|c|c|}
\hline Item $(\mathrm{cfu} / \mathrm{mL})$ & Count & $95 \%$ CI & SEM & $P$-value \\
\hline \multicolumn{5}{|l|}{ Standard plate count } \\
\hline Before UV treatment & $51,286.1$ & \multirow{2}{*}{$\begin{array}{c}(7,943,316,228) \\
(200,15,849)\end{array}$} & \multirow{2}{*}{2.2} & \multirow[t]{2}{*}{$<0.01$} \\
\hline After UV treatment & $2,344.2$ & & & \\
\hline \multicolumn{5}{|l|}{ Coliforms } \\
\hline Before UV treatment & 213.8 & $(40,1,000)$ & \multirow[t]{2}{*}{2.0} & \multirow[t]{2}{*}{$<0.01$} \\
\hline After UV treatment & 14.5 & $(3,63)$ & & \\
\hline \multicolumn{5}{|c|}{ Noncoliform gram-negative } \\
\hline Before UV treatment & $1,071.5$ & $(100,12,589)$ & \multirow[t]{2}{*}{2.9} & \multirow[t]{2}{*}{$<0.01$} \\
\hline After UV treatment & 44.7 & $(4,501)$ & & \\
\hline \multicolumn{5}{|c|}{ Environmental streptococci } \\
\hline Before UV treatment & $2,630.3$ & $(398,15,849)$ & \multirow[t]{2}{*}{2.2} & \multirow[t]{2}{*}{$<0.01$} \\
\hline After UV treatment & 39.8 & $(6,251)$ & & \\
\hline \multicolumn{5}{|l|}{ Contagious streptococci } \\
\hline Before UV treatment & 40.7 & $(16,100)$ & \multirow[t]{2}{*}{1.5} & \multirow[t]{2}{*}{$<0.01$} \\
\hline After UV treatment & 5.1 & $(2,13)$ & & \\
\hline \multicolumn{5}{|l|}{ Streptococcus agalactiae } \\
\hline Before UV treatment & 2.1 & $(0.6,8)$ & \multirow[t]{2}{*}{1.8} & \multirow[t]{2}{*}{$<0.01$} \\
\hline After UV treatment & 1.4 & $(0.4,5)$ & & \\
\hline \multicolumn{5}{|c|}{ Coagulase-negative staphylococci } \\
\hline Before UV treatment & $2,238.7$ & $(631,7,943)$ & \multirow[t]{2}{*}{1.7} & \multirow[t]{2}{*}{$<0.01$} \\
\hline After UV treatment & 190.6 & $(50,631)$ & & \\
\hline \multicolumn{5}{|l|}{ Staphylococcus aureus } \\
\hline Before UV treatment & 2.6 & $(1,6)$ & \multirow[t]{2}{*}{1.5} & \multirow[t]{2}{*}{$<0.01$} \\
\hline After UV treatment & 1.2 & $(0.5,3)$ & & \\
\hline
\end{tabular}

${ }^{1}$ All bacterial cultures were completed in duplicate. Averages of duplicate plates were used in the analysis to calculate least squares means values.

types in the present study; therefore, total coliform count was used to compare with the fecal coliform standard suggested by McGuirk (2008), which may have resulted in a more stringent requirement. God- den et al. (2005) also suggested SPC $<20,000 \mathrm{cfu} / \mathrm{mL}$ in milk for feeding calves. One hundred sixteen (43\%) samples collected after UV light treatment met all of the bacterial standards suggested by McGuirk (2008).

Table 3. Distribution of bacterial counts in nonsaleable milk samples collected before $(\mathrm{n}=272)$ and after $(\mathrm{n}$ $=272$ ) UV treatment on 9 Pennsylvania dairy farms

\begin{tabular}{|c|c|c|c|c|c|c|}
\hline \multirow[b]{2}{*}{ Item ( $\%$ of total samples) } & \multicolumn{6}{|c|}{ Bacterial count (no.) } \\
\hline & 0 & $<100$ & $<5,000$ & $<10,000$ & $<20,000$ & $<100,000$ \\
\hline \multicolumn{7}{|l|}{ Standard plate count } \\
\hline Before UV treatment & 0 & 0 & 18 & 30 & 42 & 64 \\
\hline After UV treatment & 1 & 8 & 64 & 74 & 84 & 94 \\
\hline \multicolumn{7}{|l|}{ Coliform } \\
\hline Before UV treatment & 17 & 44 & 80 & 80 & 84 & 91 \\
\hline After UV treatment & 47 & 71 & 96 & 97 & 98 & 98 \\
\hline \multicolumn{7}{|l|}{ Noncoliform gram-negative } \\
\hline Before UV treatment & 12 & 28 & 60 & 68 & 75 & 88 \\
\hline After UV treatment & 36 & 57 & 89 & 95 & 96 & 99 \\
\hline \multicolumn{7}{|l|}{ Environmental streptococci } \\
\hline Before UV treatment & 4 & 11 & 56 & 64 & 71 & 85 \\
\hline After UV treatment & 29 & 62 & 92 & 95 & 96 & 98 \\
\hline \multicolumn{7}{|l|}{ Contagious streptococci } \\
\hline Before UV treatment & 42 & 61 & 86 & 89 & 92 & 96 \\
\hline After UV treatment & 67 & 84 & 99 & 100 & 100 & 100 \\
\hline \multicolumn{7}{|l|}{ Streptococcus agalactiae } \\
\hline Before UV treatment & 91 & 91 & 95 & 96 & 99 & 99 \\
\hline After UV treatment & 94 & 96 & 100 & 100 & 100 & 100 \\
\hline \multicolumn{7}{|c|}{ Coagulase-negative staphylococci } \\
\hline Before UV treatment & 0 & 2 & 74 & 83 & 88 & 96 \\
\hline After UV treatment & 10 & 38 & 92 & 94 & 96 & 98 \\
\hline \multicolumn{7}{|l|}{ Staphylococcus aureus } \\
\hline Before UV treatment & 79 & 87 & 99 & 100 & 100 & 100 \\
\hline After UV treatment & 94 & 99 & 100 & 100 & 100 & 100 \\
\hline
\end{tabular}


Table 4. Least squares means of log reduction and percentage log reduction in bacteria counts following UV treatment of nonsaleable milk fed to calves on 9 Pennsylvania dairy farms

\begin{tabular}{|c|c|c|c|c|c|c|}
\hline \multirow[b]{2}{*}{ Item } & \multicolumn{3}{|c|}{$\log _{\text {reduction }}{ }^{1}$} & \multicolumn{3}{|c|}{ Percentage log reduction ${ }^{2}$} \\
\hline & $\mathrm{n}$ & LSM & SEM & $\mathrm{n}$ & LSM & SEM \\
\hline Standard plate count & 272 & 1.34 & 0.30 & 272 & 28.64 & 6.37 \\
\hline Coliforms & 247 & 1.27 & 0.61 & 226 & 57.84 & 18.70 \\
\hline Noncoliform gram-negative & 250 & 1.48 & 0.52 & 240 & 53.26 & 15.95 \\
\hline Environmental streptococci & 265 & 1.85 & 0.48 & 260 & 55.31 & 12.80 \\
\hline Contagious streptococci & 185 & 1.37 & 0.75 & 160 & 71.62 & 18.26 \\
\hline Streptococcus agalactiae ${ }^{3}$ & 27 & 1.92 & 1.51 & 25 & 62.72 & 27.23 \\
\hline Coagulase-negative staphylococci & 271 & 1.07 & 0.31 & 271 & 32.76 & 10.06 \\
\hline Staphylococcus aureus & 58 & 1.67 & 0.61 & 58 & 82.21 & 26.63 \\
\hline
\end{tabular}

The percent of samples collected after UV treatment that met individual suggested standards for SPC, CC, SA, NC, ES, CS, and CNS are 74, 47, 94, 89, 92, 99, and $92 \%$, respectively (Table 3 ). Eighty-four percent of samples collected after UV treatment contained SPC $<20,000 \mathrm{cfu} / \mathrm{mL}$, meeting the standard suggested by Godden et al. (2005). Currently, no recommendations exist for SAG counts in milk fed to calves.

Log reduction in bacterial populations is often used as a measure of bacterial inactivation efficacy (Miller et al., 2012). Weighted least squares means, standard errors of means, and number of comparisons included in each estimate for log reduction and percentage log reduction are shown in Table 4 . Samples with zero log reduction due to no bacterial isolates before UV light treatment were not analyzed to avoid biasing the output. However, negative log reductions, observed when posttreatment samples contained greater numbers of bacteria than pretreatment samples, were included in the analysis. An apparent increase in a bacteria type may have occurred as an artifact of reduction in another bacteria type allowing the first bacteria to grow more efficiently in the culture media. Random sampling, or increased milk temperature as a result of UV treatment, as has also been reported by Krishnamurthy et al. (2007, 2008) and Palgan et al. (2011), combined with incomplete inactivation may allow for higher bacterial populations posttreatment compared with pretreatment.

Elizondo-Salazar et al. (2010) recommended the use of percentage log reduction rather than log reduction, which allows comparison among samples with different initial bacteria counts. Although the initial bacteria counts in the present study were higher than those reported by Elizondo-Salazar et al. (2010), the use of a percentage log reduction of $50 \%$ remains a valid benchmarking goal. If an initial count of 3,000,000 cfu/
$\mathrm{mL}$ was observed, a percentage log reduction of $50 \%$ would result in a final count of approximately 1,700 $\mathrm{cfu} / \mathrm{mL}$. If these initial counts were for coliforms, the final counts would be unacceptable, but for most bacteria types, a percentage log reduction of $50 \%$ should ensure a final bacterial content acceptable for feeding calves. A percentage log reduction $>50 \%$ occurred in 6 of the 8 bacteria types analyzed in the current study. Standard plate count and CNS were reduced by 28.64 and $32.76 \%$, respectively (Table 4). Elizondo-Salazar et al. (2010) found a $>50 \% \log$ reduction in all bacteria types mentioned in the present study, with the exception of SAG and SA, which were not isolated in samples collected for that study, using heat pasteurization.

Effectiveness of UV light for bacterial inactivation, as measured by log reduction and percentage log reduction, appears to be different for different types of bacteria (Table 4). Greater than $1 \log$ reduction was achieved in each of the 8 bacteria types analyzed in our study. However, log reduction was greatest for SAG (1.92 log $\mathrm{cfu} / \mathrm{mL}$ ) and percentage log reduction was greatest for SA bacteria $(82.21 \%)$. Log reduction of CNS bacteria was $0.85 \log _{10} \mathrm{cfu} / \mathrm{mL}$ less than that observed for SAG. Likewise, the percentage log reduction observed in SA was 2.9 times greater than that observed for SPC (Table 4). An effect of bacteria type on UV light treatment efficacy has also been reported by Engin and Yuceer, (2012), who found that UV light treatment reduced coliform and Staphylococcus bacteria by approximately 4 and $3 \log _{10} \mathrm{cfu} / \mathrm{mL}$, respectively. However, only a 2-log decrease was observed in aerobic bacteria. These results suggest that UV light treatment may not be equally effective against all types of bacteria. This finding is important to consider if dairy farmers desire to reduce counts of bacteria less susceptible to UV light. 


\section{CONCLUSIONS}

Samples of nonsaleable waste milk collected for the current study contained high populations of bacteria relative to results reported in similar studies. Ultraviolet light effectively inactivated bacteria in 6 of the 8 bacteria types analyzed in the present study by achieving a percent $\log$ reduction greater than $50 \%$. Additionally, a proportion of samples collected after UV light treatment did meet suggested bacterial standards for milk for feeding to calves. Total solids percentages were different among batches of milk, and significantly reduced UV treatment effectiveness in some bacteria types. Overall, UV light treatment may be effective for some, but not all, bacteria types found in nonsaleable waste milk. Thus, farmers should take into account the bacteria types that may need to be reduced when considering the purchase of a UV treatment system. The effectiveness of UV light for inactivation of Mycoplasma ssp., Mycobacterium avium ssp. paratuberculosis, and Salmonella ssp. was not assessed in the current study.

\section{ACKNOWLEDGMENTS}

This research was supported by the Arthur W. Nesbitt Faculty Program Development Award with additional support by Zoetis Inc. (Florham Park, NJ).

\section{REFERENCES}

Altic, L. C., M. T. Rowe, and I. R. Grant. 2007. UV light inactivation of Mycobacterium avium ssp. paratuberculosis in milk as assessed by FASTPlaqueTB phage assay and culture. Appl. Environ. Microbiol. 73:3728-3733.

Donaghy, J., M. Keyser, J. Johnston, F. P. Cilliers, P. A. Gouws, and M. T. Rowe. 2009. Inactivation of Mycobacterium avium ssp. paratuberculosis in milk by UV treatment. Lett. Appl. Microbiol. 49:217-221.

Elizondo-Salazar, J. A., C. M. Jones, and A. J. Heinrichs. 2010. Evaluation of calf milk pasteurization systems on 6 Pennsylvania dairy farms. J. Dairy Sci. 93:5509-5513.

Engin, B., and Y. K. Yuceer. 2012. Effects of ultraviolet light and ultrasound on microbial quality and aroma-active components of milk. J. Sci. Food Agric. 92:1245-1252.

Fecteau, G., P. Baillargeon, R. Higgins, J. Pare, and M. Fortin. 2002. Bacterial contamination of colostrum fed to newborn calves in Quebec dairy herds. Can. Vet. J. 43:523-527.

FDA (Food and Drug Administration). 2000. Code of Federal Regulations Title 21. Accessed Feb. 26, 2014. http://www.gpo.gov/fdsys/ pkg/CFR-2012-title21-vol3/pdf/CFR-2012-title21-vol3-sec179-39. pdf.
FDA (Food and Drug Administration). 2013. Grade A pasteurized milk ordinance. Accessed May 30, 2013. http://www.fda.gov/ downloads/Food/GuidanceRegulation/UCM291757.pdf.

Godden, S. M., J. R. Fetrow, J. M. Feirtag, L. R. Green, and S. J. Wells. 2005. Economic analysis of feeding pasteurized nonsaleable milk versus conventional milk replacer to dairy calves. J. Am. Vet. Med. Assoc. 226:1547-1554.

Guerrero, B., and G. V. Barbosa-Canovas. 2004. Advantages and limitations on processing foods by UV light. Food Sci. Technol. Int. 10:137-147.

Houser, B. A., S. C. Donaldson, S. I. Kehoe, A. J. Heinrichs, and B. M. Jayarao. 2008. A survey of bacteriological quality and the occurrence of Salmonella in raw bovine colostrum. Foodborne Pathog. Dis. $5: 853-858$

Jamaluddin, A. A., D. W. Hird, M. C. Thurmond, and T. E. Carpenter. 1996. Effect of preweaning feeding of pasteurized and nonpasteurized milk on postweaning weight gain of heifer calves on a Californian dairy. Prev. Vet. Med. 28:91-99.

Jayarao, B. M., S. R. Pillai, A. A. Sawant, D. R. Wolfgang, and N. V. Hegde. 2004. Guidelines for monitoring bulk tank milk somatic cell and bacterial counts. J. Dairy Sci. 87:3561-3573.

Jorgensen, M. A., P. C. Hoffman, and A. J. Nytes. 2006. Case study: A field survey of on-farm milk pasteurization efficacy. Prof. Anim. Sci. 22:472-476.

Koutchma, T. N., L. J. Forney, and C. I. Moraru. 2009. Ultraviolet Light in Food Technology: Principles and Applications. CRC Press, Boca Raton, FL.

Krishnamurthy, K., A. Demirci, and J. M. Irudayaraj. 2007. Inactivation of Staphylococcus aureus in milk using flow-through pulsed UV-light treatment system. J. Food Sci. 72:M233-M239.

Krishnamurthy, K., A. Demirci, and J. M. Irudayaraj. 2008. Inactivation of Staphylococcus aureus in milk and milk foam by pulsed UV light treatment and surface response modeling. Trans. Am. Soc. Agric. Biologic. Eng. 51:2083-2090.

Matak, K. E., J. J. Churey, R. W. Worobo, S. S. Sumner, E. Hovingh, C. R. Hackney, and M. D. Pierson. 2005. Efficacy of UV light for the reduction of Listeria monocytogenes in goat's milk. J. Food Prot. 68:2212-2216.

McGuirk, S. M. 2008. Disease management of dairy calves and heifers. Vet. Clin. North Am. Food Anim. Pract. 24:139-153.

Miller, B. M., A. Sauer, and C. I. Moraru. 2012. Inactivation of Escherichia coli in milk and concentrated milk using pulsed-light treatment. J. Dairy Sci. 95:5597-5603.

Moore, D. A., J. Taylor, M. L. Hartman, and W. M. Sischo. 2009. Quality assessments of waste milk at a calf ranch. J. Dairy Sci. 92:3503-3509.

Palgan, I., I. M. Caminiti, A. Munoz, F. Noci, P. Whyte, D. J. Morgan, D. A. Cronin, and J. G. Lyng. 2011. Effectiveness of high intensity light pulses (HILP) treatments for the control of Escherichia coli and Listeria innocua in apple juice, orange juice and milk. Food Microbiol. 28:14-20.

Stabel, J. R. 2001. On-farm batch pasteurization destroys Mycobacterium paratuberculosis in waste milk. J. Dairy Sci. 84:524-527.

Stabel, J. R., S. Hurd, L. Calvente, and R. F. Rosenbusch. 2004. Destruction of Mycobacterium paratuberculosis, Salmonella spp., and Mycoplasma spp. in raw milk by a commercial on-farm hightemperature, short-time pasteurizer. J. Dairy Sci. 87:2177-2183.

USDA. 2010. Heifer calf health and management practices on U.S. dairy operations, 2007. Natl. Anim. Health Monitoring System, Ft. Collins, CO. 